\title{
Suffix combinations in Bulgarian: parsability and hierarchy-based ordering
}

\author{
Stela Manova
}

Received: 3 July 2008/ Accepted: 3 January 2010/Publihsed online: 15 April 2010

(C) The Author(s) 2010. This article is published with open access at Springerlink.com

\begin{abstract}
This article extends the empirical scope of the most recent approach to affix ordering, the Parsability Hypothesis (Hay 2001, 2002, 2003) or ComplexityBased Ordering (CBO) (Plag 2002; Hay and Plag 2004; Plag and Baayen 2009), to the inflecting-fusional morphological type, as represented by the South Slavic language Bulgarian. In order to account properly for the structure of the Bulgarian word, I distinguish between suffixes that are in the derivational word slot and suffixes that are in the inflectional word slot and show that inflectional suffix combinations are more easily parsable than derivational suffix combinations. Derivational suffixes participate in mirror-image combinations of AB-BA type and can be also attached recursively. The order of 12 out of the 22 derivational suffixes under scrutiny in this article is thus incompatible with CBO. With respect to recursiveness and productivity, the Bulgarian word exhibits three domains of suffixation (in order of increasing productivity): (1) a non-diminutive derivational domain, where a suffix may attach recursively on non-adjacent cycles; (2) a diminutive domain, where a suffix may attach recursively on adjacent cycles; and (3) an inflectional domain, where a suffix never attaches recursively. Overall, the results of this study conform to the last revision of the Parsability Hypothesis (Baayen et al. 2009); and if we see the derivational suffix slot and the inflectional suffix slot of the Bulgarian word as parallel to the non-native stratum and the Germanic stratum respectively in English word-formation, we can conclude that suffixes that are closer to the root tend to exhibit idiosyncrasies and appear less parsable in both languages.
\end{abstract}

\footnotetext{
S. Manova $(\bowtie)$

Department of Slavic Studies, University of Vienna,

Universitätscampus AAKH, Spitalgasse 2,

Hof 3, 1090 Vienna, Austria

e-mail: stela.manova@univie.ac.at

URL: http://slawistik.univie.ac.at/mitarbeiter/manova-stela/;

http://homepage.univie.ac.at/stela.manova/
} 
Keywords Parsability · Hierarchy-based affix ordering · Derivation ·

Inflection · Bulgarian

\section{Introduction}

This article extends the empirical scope of the most recent approach to affix ordering, the Parsability Hypothesis (Hay 2001, 2002, 2003) or Complexity-Based Ordering $(\mathrm{CBO})^{1}$ (Plag 2002; Hay and Plag 2004; Plag and Baayen 2009; Zirkel, this issue), to the inflecting-fusional morphological type. The body of evidence supporting the Parsability Hypothesis in the literature so far has come primarily from English, a language with very poor inflectional morphology. Therefore, this paper tests the claims of the Parsability Hypothesis against data from Bulgarian, a South Slavic language with rich inflectional morphology.

The Parsability Hypothesis acknowledges the crucial role of processing constraints in affix ordering. It assumes a dual-route access model of morphological processing, i.e. we access derived words either as whole words or as decomposable units. Which of the two routes is preferred depends, among other things, on relative frequency, which is the ratio of the frequency of the derivative to the frequency of the base. "If the derived form is more frequent than the base it contains (illegible is more frequent than legible), then the whole-word route will have an advantage. If the derived form is less frequent than the base it contains (illiberal is less frequent than liberal), then the decomposed route will be advantaged'" (Hay 2002, p. 529). Thus the same affix can exhibit differing degrees of parsability in different morphological forms (il-in illegible is less parsable than il-in illiberal). Hay also demonstrates that relative frequency correlates with productivity, semantic transparency and phonotactics. Productive categories are semantically transparent and accessed via decomposition, whereas unproductive categories are semantically opaque and therefore accessed as whole words. Parsing is related to phonotactics in the sense that across the morpheme boundary, highly parsable affixes form combinations of phonemes that do not occur morpheme-internally. Moreover, consonant-initial suffixes are more easily parsable than vowel-initial suffixes, since consonant-initial suffixes do not (or seldom) blur the morpheme boundary via phonological and morphonological alternations, i.e. suffixes that blur the morpheme boundary are less parsable than neutral suffixes that leave the morpheme boundary intact. Thus parsability depends on different factors and occurs by gradations, which allows affixes to be ordered hierarchically according to their ability to parse. Hay argued that affixes order in such a way that more parsable affixes do not occur within less parsable affixes, since the attachment of a less separable affix to a more separable one is

\footnotetext{
${ }^{1}$ Abbreviations used in the text: ADJ-adjective, AOR-aorist, ASP-aspect, C-consonant, CBO-Complexity-Based Ordering, DEF-definite, DIM-diminutive, DSUFF-derivational suffix, GEND—gender, IND—indicative, IMP—imperative, IPFV1—primary imperfective, IPFV2—secondary imperfective, ISUFF—inflectional suffix, N-noun, NUM-number, PER-person, PFV—perfective, PL-plural, PREF-prefix, PRET-preterite, PRS—present, SG-singular, SUFF-suffix, TM-thematic marker, TNS—-tense, V-verb.
} 
difficult to process. Hay (2002) and Hay and Plag (2004) show that English suffixes can be ordered in a hierarchy of juncture strength. Affixes that follow the affix X on the hierarchy can be added to words already affixed by X, whereas affixes preceding $\mathrm{X}$ on the hierarchy cannot be attached to words containing $\mathrm{X}$. To illustrate, if there is a hierarchy of affixes A-B-C-D-X-Y-Z, then BASE-A-X-Z and BASE-C-Y-Z would be possible combinations, whereas *BASE-X-A-Z and BASE-Z-D-A would be impossible. We will refer to this type of hierarchical affix ordering as ComplexityBased Ordering (CBO), a term suggested by Plag (2002).

As already mentioned, the Parsability Hypothesis has been formulated to explain the order of English derivational affixes. Up to now, the hypothesis has been tested against data from English (Hay 2001 and later works; Plag 2002; Hay and Baayen 2002; Hay and Plag 2004; Plag and Baayen 2009; Zirkel this volume), Dutch (Baayen and Plag 2008) and Italian (Gaeta 2008). The studies on Dutch and Italian affixes, however, have not been published. Both English and Dutch are Germanic languages and display quite similar morphological organization, with Dutch inflectional morphology being a bit richer than that of English; and Italian inflectional morphology being even richer than that of Dutch. It is unclear whether degree of inflectional complexity has some impact on parsability in derivation, but Baayen and Plag (2008) conclude that (derivational) affix order in (the inflectionally richer) Dutch is less tightly constrained by parsability than in English. Gaeta (2008) also comes to some similar conclusion for the Italian derivational suffixes in comparison to English. Although inflection, like derivation, creates word structure, the Parsability Hypothesis does not make any predictions about the role of inflection and its relation to derivation in the processing of complex words. Thus in order to find some explanation of this and related issues, the present paper will, for the first time, challenge the Parsability Hypothesis with data from derivation and inflection.

The paper is organized as follows. Section 2 presents the structure of the Bulgarian word and argues for a clear differentiation between addition of suffixes in the derivational and inflectional word slots. Section 3 explains how the data were selected and the methodology used for their analysis. Sections 4 and 5 are devoted to parsability in derivation and in inflection respectively. It is shown that the derivational and the inflectional word domains are differently organized with respect to parsability. In the last Section 6, conclusions are drawn.

\section{The structure of the Bulgarian word}

Bulgarian is an inflecting language and makes a clear distinction between derivational and inflectional suffix slots (cf. Skalička 1979). Thus for the Bulgarian word, I assume a generalized structure based on the universal principle of constructional diagrammaticity (in the sense of Natural Morphology, cf. Dressler et al. 1987), i.e. addition of semantics implies addition of form; and the notion of prototype (in the sense of Cognitive Grammar, cf. Langacker 1987), i.e. the easiest way of accessing a phenomenon is via that manifestation that is most salient or otherwise most 
reflective of the phenomenon's prototype. The structure in question is (cf. Manova 2002 and later works):

\section{(1) (PREFIX)-BASE-(DERIVATIONAL SUFF)-(THEMATIC MARKER)- (INFLECTIONAL SUFF)}

The slot BASE is always occupied, and the BASE can be a root, a stem or a word. The other slots are not obligatory and, as indicated by the brackets, can be empty. In the best (i.e. easiest to analyze) case, a word will have a base accompanied by a single affix in every slot, as in the following example:

(2) pre-registr-ir- $a-m$

PREF-register-DSUFF-TM-ISUFF

'(I) register again-PRS'

Prototypically, derivation takes place in the derivational slot of the word, whereas inflection is located in the inflectional slot. TMs are recognized only in verbal morphology where they have inflectional status (cf. the discussion in Manova 2010), i.e. the TM slot of nouns and adjectives is always empty. The TM slot of verbs is either empty or always occupied by a single suffix, such that TMs serve for the identification of the inflection class of a lexeme.

Like in English, where words can have more than one derivational suffix (e.g. real-iz-ation-al), the derivational slot of the Bulgarian word can host two or more suffixes. Consider:

(3) pisa-tel-sk-i

write-DSUFF-DSUFF-ISUFF

'writer's'

(4) pisa-tel-stv-an-e

write-DSUFF-DSUFF-DSUFF-ISUFF

'writing; being a writer'

As shown in (5), diminutives from derived bases are a typical example of words with more than one derivational suffix:

(5) pisa-tel- $\check{c}-e$

write-DSUFF-DIM-ISUFF

'little writer; bad writer'

A word may also contain more than one diminutive suffix:

(6) pisa-tel-č-enc-e

write-DSUFF-DIM-DIM-ISUFF

'very little writer; very bad writer'

As can be seen from (5) and (6), diminutive suffixes always follow the other derivational suffixes, i.e. a diminutive suffix is always the last suffix in the 
derivational slot of a Bulgarian word. ${ }^{2}$ We will use this fact when presenting the data (Sect. 3) and when ordering them hierarchically (Sect. 4). Thus in all tables in this paper, the diminutive suffixes are always listed after the other derivational suffixes.

The inflectional slot of the Bulgarian word can have more than one suffix, too:

(7) pisatel-i-te

writer-PL-DEF

'the writers'

(8) kup-i-xme

kup-TM-TNS/PER/NUM

'we bought-AOR'

The example in (9) exhibits more than one suffix in both derivational and inflectional slots:

(9) pisa-tel-sk-a-ta

write-DSUFF-DSUFF-ISUFF-ISUFF

'the female writer's'

Stacking of prefixes is also possible:

iz-po-pre-săx-n-a

PREF-PREF-PREF-dry-DSUFF-ISUFF

'(I) totally dry'

Crucially, the assumed structural differentiation of derivational and inflectional suffix slots is of importance for the proper functioning of morphological rules. One expects derivatives belonging to the same word-class and terminating in homophonous derivational suffixes to be treated in the same way by the morphology of the language. I will illustrate the point with the two homophones of the suffix $-k-a$, cited as $-k_{1}-a$ and $-k_{2}-a$ in the following examples. The first homophone, $-k_{1^{-}} a$, derives result nouns (11a), whereas the second homophone, $-k_{2}-a$, forms female personal nouns (11b). In the examples below, all a. instances are related to $-k_{1}-a$ and all $\mathrm{b}$. instances to $-k_{2}-a$.

a. snim- $\varnothing$ - $a m$ '(I) take a picture' $\rightarrow \mathrm{N}$ FEM snim- $k_{1}-a$ 'a photograph'

b. profes-or-ø 'professor' $\rightarrow \mathrm{N}$ FEM profesor- $k_{2}-a$ 'female professor'

(12) gives all possible inflectional forms of snimka 'a photograph' (12a) and profesorka 'a female teacher' (12b) in Bulgarian:

\footnotetext{
2 The final position of the diminutive suffixes in the derivational slot is due to their non-prototypical derivational status, cf. Dressler (1989) and Manova (2005).
} 

a. snim- $k_{1}-a$ 'a photograph' $\rightarrow$ DEF snim- $k_{1}-a-t a$, PL snim- $k_{1}-i$, PL DEF snim- $k_{1}-i$-te
b. professor- $k_{2}-a \rightarrow$ DEF professor- $k_{2}-a-t a$, PL professor- $k_{2}-i$, PL DEF professor- $k_{2}-i$-te

As can be seen from these examples $-k_{1}-a$ and $-k_{2}-a$ are followed by the same inflection, i.e. inflectional morphology does not distinguish between $-k_{1}-a$ and $-k_{2}-a$.

In (13a) and (13b) all possible derivatives from bases terminating in $-k_{1}-a$ and $-k_{2}-a$ are listed:

$$
\begin{aligned}
& \text { a. snim- } k_{1}-a \rightarrow \text { ADJ snim- } k_{1}-o v-\varnothing \text { 'photo-" } \\
& \text { snim- } k_{1}-a \rightarrow \text { DIM snim- } \check{c}_{2}-i c-a \\
& \text { b. profesor- } k_{2}-a \rightarrow \mathrm{ADJ} \emptyset \\
& \text { profesor- } k_{2}-a \rightarrow \text { DIM } \varnothing
\end{aligned}
$$

(13) undoubtedly shows that derivational morphology, unlike inflectional morphology, makes a clear distinction between $-k_{1}-a$ and $-k_{2}-a$ : $-k_{1}-a$ allows further suffixation whereas $-k_{2}-a$ does not, i.e. is closing ${ }^{3}$ (Manova 2008).

Thus the examples in (12) and (13) are evidence that derivation and inflection differ with respect to further suffixation. For derivational morphology, $-k_{1}-a$ and $-k_{2}-a$ are two different suffixes and behave differently with respect to further suffixation. For inflectional morphology, however, words terminating in $-k_{1}-a$ and $-k_{2}-a$ belong to the same inflectional class and thus receive the same set of inflectional suffixes, which means the same further suffixation. This clearly different behaviour of derivation and inflection in regard to further suffixation supports our postulation of two independent word slots.

Based on the above observations, I will discuss parsability in derivation and inflection separately, i.e. I assume two different domains of parsability-one derivational and one inflectional. There is also a practical advantage of the application of such an approach to Bulgarian word structure; the results obtained for the Bulgarian word-formation would be comparable with the investigations of the parsability of the English word-formation. In English, the problem with the ordering of inflectional suffixes does not exist, since English words are either non-inflected or have only one inflectional suffix.

\section{Data and method}

\subsection{Sources of data}

The Parsability Hypothesis is basically a claim about statistical tendencies and the proper test of the hypothesis requires extensive use of electronic resources that

\footnotetext{
${ }^{3}$ Not only $*_{-} k_{2}-a+-o v$ and $*_{-} k_{2}-a+-i c a$ are impossible. In Bulgarian, the suffix $-k_{2}-a$ cannot be followed by another derivational suffix.
} 
unfortunately are not available for Bulgarian, in the form they exist for English. The electronic corpora of Bulgarian are relatively small and not annotated for carrying out morphological research, i.e. the corpora are annotated at the level of word and are thus appropriate for investigation of combinations of words but not for morpheme analyses. Moreover, in a language with rich inflectional morphology derivational suffixes, since almost always followed by inflectional suffixes, are not word-final, which constitutes a further obstacle to investigations of derivational morphology. The main trouble, however, causes allomorphy. A Bulgarian derivational affix often appears in different shapes, which makes it difficult to segment (parse) automatically (see (14) in Sect. 4).

There are two major corpora of Bulgarian: the National Corpus of Bulgarian (since April 2009, available at: http://www.ibl.bas.bg/en/BGNC_classific_en.htm) and the corpus of the BulTreeBank project (http://www.bultreebank.org/), both maintained by the Bulgarian Academy of Sciences but developed by competing teams. Since the National Corpus of Bulgarian is very young, I can report mainly experience with the BulTreeBank corpus. Unfortunately, the use of this corpus is very problematic. The first serious problem with the corpus is that it is not freely accessible. One has to submit a formal request on the basis of which somebody from the staff engaged in the corpus will check up to 20 items for him/her. Additionally, although the corpus contains over 90 million words, there is often a problem with low frequency words, for which a corpus search often does not give any results. Therefore, in order to avoid the problem with low-frequency items, the author will refer to the Internet (Google) rather than to corpora when information about the occurrence of a particular word form is needed for the analysis. ${ }^{4}$

Thus, the approach adopted herein relies primarily on evidence from dictionaries and grammars rather than on electronic corpora.

\subsection{Selecting the data}

The majority of the Bulgarian derivational suffixes are nominalizing, adjectivizing suffixes are fewer in number and there are only very few verbalizing suffixes. Most verbalizers are either of foreign origin, such as the German -(izi)ir-a- and the Greek -Vs-a- (-a- after the suffix indicates that both suffixes are always followed by the TM $-a$-), or aspectual suffixes (e.g. săn 'dream' $\rightarrow$ săn- $u v-a-m$ 'dream-ASPTM-ISUFF'). Aspectual suffixes are, however, inflectional material, i.e. such verbs are not derived through derivational suffixation (cf. the discussion in Manova 2010). Additionally, verbs formed by foreign verbalizers differ from native verbs in aspectual behaviour and are thus somehow outside the system of the Bulgarian verbs. A Bulgarian verb is either perfective or imperfective, whereas -ira-verbs are

\footnotetext{
${ }^{4}$ For a psycholinguistic project on Bulgarian and Italian verb morphology (cooperation of Scuola Normale Superiore (Pisa), University of Trento, New Bulgarian University (Sofia) and University of Vienna) we used as sources of data (whole words) Internet (Google) and the BulTreeBank corpus and compared the results obtained. The search in the BulTreeBank corpus was run in Bulgaria by Armina Janyan who had a direct access to the corpus. The search in the corpus and the Google search converged for the high frequency verbs, but for the low-frequency verbs the corpus often did not provide information, which forced us to rely on Google exclusively.
} 
biaspectual; all derived verbs in Bulgarian but -Vsa- verbs are imperfective (cf. Manova 2007, 2010). The attachment of a foreign verbalizer results in an $a$-verb (i.e. a verb with the PRS TM $-a$-) whereas the native verbalizers derive $e$-verbs and $i$-verbs only (i.e. verbs with the PRS TMs $-e$ - and $-i$-), $j$ the conjugation classes of the Bulgarian verbs are listed in the Appendix. Thus, in order to avoid any 'illegal' influence on affix order because of a selection of suffixes that exhibit specific peculiarities in combinability, verbalizing suffixes are excluded from the dataset. However, the omission of the verbalizing suffixes should not create any problem for the testing of the Parsability Hypothesis since parsability ordering is expected for all affixes in a language and there is no evidence in the literature so far that the set of affixes under scrutiny can influence the results of a parsability study.

As regards the selection of the nominalizing suffixes, suffixes that are in the derivational slot of the word but whose status as derivational suffixes can be doubted, such as suffixes for derivation of female personal nouns from male personal nouns (cf. Manova 2002, 2005), as well as the suffix - vne that derives action nouns and attaches to every imperfective verb, are deliberately excluded from the dataset, since the fact that such suffixes do not allow attachment of other derivational suffixes can be due to their inflectional character (Manova 2008). Suffixes that seem to serve for derivational purposes but are inflectional due to their placement in the inflectional slot of the word are also excluded, e.g. the diminutivization of vojnik 'soldier' takes place through the attachment of the inflection $-e$, which gives vojnič- $e$ 'little soldier'. It is clear that the inflectional suffix $-e$ cannot be followed by a derivational suffix. This fact makes the suffix $-e$ irrelevant to the analysis of the combination of derivational suffixes, and the suffix is therefore not considered.

As regards the adjectival suffixes under investigation herein, they were selected because they combine with most of the nominal suffixes under scrutiny in this paper. The body of evidence for the analysis of derivational morphology constitute the 22 derivational suffixes listed in Table 1.

As already declared in the previous section, the diminutive suffixes are separated from the other derivational suffixes and listed at the end of Table 1. Each of the two sets of suffixes in table 1 is ordered alphabetically using the Microsoft Word alphabetic-ordering function. This ordering is also preserved in the other two tables, Tables 2 and 3, in this section.

Table 2 lists all derivational suffixes in Bulgarian that can follow the 22 suffixes from table 1 and provides an overview of the way suffixes combine in Bulgarian, which may be helpful for readers unfamiliar with this language. Table 2 will also serve for illustration of closing suffixes. A closing suffix is a suffix that cannot be followed by another suffix of the same type in a given language, i.e. a closing derivational suffix is never followed by another derivational suffix and a closing inflectional suffix is never followed by another inflectional suffix (cf. Aronoff and Fuhrhop 2002; Manova 2009a). A '?', see suffix -izăm (Table 2), means that there are only one or two words derived according to the illustrated pattern, and/or that these examples may be questioned by native speakers. In our case, the form ?sozial$i z \breve{a r m}$-če 'socialism-DIM' is the only instance of a diminutive derived from an -izăm 
Table 1 The 22 derivational suffixes under investigation with their syntactic and semantic specification and with examples

\begin{tabular}{|c|c|c|c|c|}
\hline SUFF & $\begin{array}{l}\text { Syntactic category } \\
\text { of the derivative }\end{array}$ & Semantics of SUFF & Examples & Translations \\
\hline$-(e)$ stvo & $\mathrm{N}$ & nomina essendi & $\begin{array}{l}\text { rod-stvo } \\
\text { măž-estvo }\end{array}$ & $\begin{array}{l}\text { kinship } \\
\text { manliness }\end{array}$ \\
\hline$-(i t) b a$ & $\mathrm{~N}$ & $\begin{array}{l}\text { nomina actionis } \\
\& \text { patientis }\end{array}$ & $\begin{array}{l}\text { svat-ba } \\
\text { se-itba }\end{array}$ & $\begin{array}{l}\text { wedding } \\
\text { sowing }\end{array}$ \\
\hline -(iz) acija & $\mathrm{N}$ & $\begin{array}{l}\text { nomina actionis \& } \\
\text { patientis }\end{array}$ & $\begin{array}{l}\text { motiv-acija } \\
\text { privat-izacija }\end{array}$ & $\begin{array}{l}\text { motivation } \\
\text { privatization }\end{array}$ \\
\hline$-(l) i v$ & ADJ & qualitative $\mathrm{ADJ}$ & $\begin{array}{l}\text { mărzel-iv } \\
\text { rabot-liv }\end{array}$ & $\begin{array}{l}\text { lazy } \\
\text { industrious }\end{array}$ \\
\hline$-(n) i c a$ & $\mathrm{~N}$ & nomina loci & $\begin{array}{l}\text { voden-iča } \\
\text { mel-nica }\end{array}$ & $\begin{array}{l}\text { watermill } \\
\text { mill }\end{array}$ \\
\hline -(on)en & ADJ & $\begin{array}{l}\text { relational \& } \\
\text { qualitative ADJs }\end{array}$ & $\begin{array}{l}\text { trud-en } \\
\text { klasifikaci-onen }\end{array}$ & $\begin{array}{l}\text { difficult } \\
\text { classificational }\end{array}$ \\
\hline$-e c$ & $\mathrm{~N}$ & nomina agentis & tvor-eč & artist \\
\hline -ik/-nik/-ovnik & $\mathrm{N}$ & nomina actoris & $\begin{array}{l}\text { vojn-ik } \\
\text { uče-nik } \\
\text { bunt-ovnik }\end{array}$ & $\begin{array}{l}\text { soldier } \\
\text { pupil } \\
\text { rebel }\end{array}$ \\
\hline  & $\mathrm{N}$ & nomina abstracta & socil-izăm & socialism \\
\hline -ost & $\mathrm{N}$ & nomina essendi & mil-ost & mercy \\
\hline$-o t a$ & $\mathrm{~N}$ & nomina essendi & kras-ota & beauty \\
\hline$-o v /-e v$ & ADJ & $\begin{array}{l}\text { relational \& } \\
\text { qualitative ADJs }\end{array}$ & $\begin{array}{l}\text { roz-ov } \\
\text { slänč-ev }\end{array}$ & $\begin{array}{l}\text { rosy } \\
\text { sunny }\end{array}$ \\
\hline $\begin{array}{l}\text {-ski/-ičeski/-eski/ } \\
\text {-ki/-ovsk/-Vnski }\end{array}$ & ADJ & relational ADJs & $\begin{array}{l}\text { det-ski } \\
\text { turist-íceski } \\
\text { učenič-eski } \\
\text { vojniš-ki etc. }^{\text {a }}\end{array}$ & $\begin{array}{l}\text { child- } \\
\text { tourist- } \\
\text { pupil- } \\
\text { soldier- }\end{array}$ \\
\hline$-t e l$ & $\mathrm{~N}$ & nomina agentis & uči-tel & teacher \\
\hline -Vnie & $\mathrm{N}$ & $\begin{array}{l}\text { nomina actionis } \\
\& \text { patientis }\end{array}$ & $\begin{array}{l}\text { koleb-anie } \\
\text { upravl-enie }\end{array}$ & $\begin{array}{l}\text { hesitation } \\
\text { government \& } \\
\text { governing }\end{array}$ \\
\hline \multicolumn{5}{|l|}{ DIMINUTIVE } \\
\hline$-\breve{c e}$ & $\mathrm{~N}$ & deminutiva & prăst-čce & small finger \\
\hline$-c e$ & $\mathrm{~N}$ & deminutiva & pisăm-ce & small letter \\
\hline -ence & $\mathrm{N}$ & deminutiva & det-ence & small child \\
\hline$-i c a$ & $\mathrm{~N}$ & deminutiva & žen-ica & small woman \\
\hline$-i \check{c} \breve{a} k$ & ADJ & deminutiva & krat-ičăk & shorter \\
\hline$-k a$ & $\mathrm{~N}$ & deminutiva & $k n i z \breve{z}-k a$ & small book \\
\hline$-(o v) a t$ & ADJ & $\begin{array}{l}\text { deminutiva } \\
\text { deminutiva }\end{array}$ & $\begin{array}{l}\text { rozov-at } \\
\text { grub-ovat }\end{array}$ & $\begin{array}{l}\text { rosy-like } \\
\text { somewhat rude }\end{array}$ \\
\hline
\end{tabular}

In case of allomorphy, each allomorph is exemplified

${ }^{a}$ All allomorphs of the suffix - ski are illustrated in (14) 
Table 2 Combinability of the 22 Bulgarian derivational suffixes (with all derivational suffixes in Bulgarian)

\begin{tabular}{|c|c|c|c|c|}
\hline $\mathrm{SUFF}_{1}$ & $\begin{array}{l}\text { Syntactic } \\
\text { category } \\
\text { of } \text { SUFF }_{1}\end{array}$ & $\begin{array}{l}\text { SUFF }_{2} \text { according } \\
\text { to its syntactic } \\
\text { category }\end{array}$ & $\begin{array}{l}\text { Examples of } \\
\text { SUFF }_{1}-\text { SUFF }_{2} \\
\text { combinations }\end{array}$ & Translations \\
\hline$-(e)$ stvo & $\mathrm{N}$ & ADJ: -en & măž-estv-en, rod-stv-en & manly, kindred \\
\hline \multirow[t]{3}{*}{$-(i t) b a$} & \multirow[t]{3}{*}{$\mathrm{N}$} & $\mathrm{N}:-a r$ & svat-b-ar & wedding-guest \\
\hline & & $\mathrm{DIM}_{\mathrm{N}}:-i c a$ & svat-b-ica & wedding-DIM \\
\hline & & ADJ: -en & svat-b-en, se-itb-en & wedding-, sowing- \\
\hline \multirow[t]{2}{*}{$-(i z) a c i j a$} & \multirow[t]{2}{*}{$\mathrm{N}$} & $\operatorname{DIM}_{\mathrm{N}}:-k a$ & $\begin{array}{l}\text { privat-izacij-ka, } \\
\text { motiv-acij-ka }\end{array}$ & $\begin{array}{l}\text { privatisation-DIM, } \\
\text { motivation-DIM }\end{array}$ \\
\hline & & ADJ: -onen & $\begin{array}{l}\text { privat-izaci-onen, } \\
\text { motiv-aci-onen }\end{array}$ & $\begin{array}{l}\text { privatisation-, } \\
\text { motivation- }\end{array}$ \\
\hline \multirow[t]{2}{*}{$-(l) i v$} & \multirow[t]{2}{*}{ ADJ } & $\mathrm{N}:-o s t,-e c$ & $\begin{array}{l}\text { rabot-liv-ost, } \\
\text { mărzel-iv-ec }\end{array}$ & $\begin{array}{l}\text { industriousness, } \\
\text { lazy person }\end{array}$ \\
\hline & & $\mathrm{DIM}_{\mathrm{ADJ}}:-i c \breve{a} \breve{k}$ & rabot-liv-ičăk & hard-working-DIM \\
\hline \multirow[t]{3}{*}{$-(n) i c a$} & \multirow[t]{3}{*}{$\mathrm{N}$} & $\mathrm{N}:-a r$ & voden-ǐ̌-ar & watermiller \\
\hline & & DIM $_{N}:-k a$ & $\begin{array}{l}\text { voden-ič-ka, } \\
\text { mel-nič-ka }\end{array}$ & $\begin{array}{l}\text { watermill-DIM, } \\
\text { mill-DIM }\end{array}$ \\
\hline & & ADJ: -en & voden-ič-en, mel-nič-en & watermill-, mill- \\
\hline -(on)en & ADJ & $\mathrm{N}:-o s t,-i c a,-i n a$ & $\begin{array}{l}\text { trud-n-ost, vod-en-ica, } \\
\text { stud-en-ina, } \\
\text { măč-n-ota } \\
\text { trud-n-ičăk }\end{array}$ & $\begin{array}{l}\text { difficulty, water mill, } \\
\text { coolness, } \\
\text { difficultness } \\
\text { difficult-DIM }\end{array}$ \\
\hline \multirow[t]{2}{*}{$-e c$} & \multirow[t]{2}{*}{$\mathrm{N}$} & $\mathrm{N}:-e s t v o$ & tvor-č-estvo & artistic work, creativity \\
\hline & & ADJ: $-k i /-e s k i$ &  & death-like, fighting \\
\hline \multirow[t]{2}{*}{$\begin{array}{l}-i k /-n i k / \\
\text {-ovnik }\end{array}$} & \multirow[t]{2}{*}{$\mathrm{N}$} &  & $\begin{array}{l}\text { vojn-ič-estvo, } \\
\text { klevet-nič-estvo, } \\
\text { bunt-ovnič-estvo, } \\
\text { vojn-ik-lăk }\end{array}$ & $\begin{array}{l}\text { being a soldier, } \\
\text { slander, } \\
\text { revolutionary activities, } \\
\text { being a soldier }\end{array}$ \\
\hline & & ADJ: -ki/-ičeski & vojn-iš-ki, klevet-nič-eski & soldier's, slanderous \\
\hline  & $\mathrm{N}$ & $? \mathrm{DIM}_{\mathrm{N}}:-\check{c} e$ & ?socil-izăm-če & socialism-DIM \\
\hline \multirow[t]{3}{*}{$-o s t$} & \multirow[t]{3}{*}{$\mathrm{N}$} & $\mathrm{N}:-n i k,-i n j a$ & xub-ost-nik, mil-ost-inja & rascal, alms \\
\hline & & $\mathrm{DIM}_{\mathrm{N}}:-\check{c} i c a$ & $x u b-o s t-c ̌ i c a$ & beauty-DIM \\
\hline & & ADJ: $-e n,-i v$ & rad-ost-en, mil-ost-iv & joyous, merciful \\
\hline \multirow[t]{2}{*}{$-o t a$} & \multirow[t]{2}{*}{$\mathrm{N}$} & ?DIM $\mathrm{N}_{\mathrm{N}}:-i c ̌ k a$ & $? k r a s-o t-i c ̌ k a$ & beauty-DIM \\
\hline & & ADJ: -en & sam-ot-en & lonely \\
\hline \multirow[t]{4}{*}{$-o v /-e v$} & \multirow[t]{4}{*}{ ADJ } & $\mathrm{N}:-o s t,-i n a$ & $\begin{array}{l}\text { roz-ov-ost, slănč-ev-ost, } \\
\text { roz-ov-ina }\end{array}$ & $\begin{array}{l}\text { rosiness, sunniness, } \\
\text { rosiness }\end{array}$ \\
\hline & & ADJ: $-s k i$ & djad-ov-ski & grandpa-like \\
\hline & & $\mathrm{DIM}_{\mathrm{ADJ}}:-i c \breve{a} k,-a t$ & $\begin{array}{l}\text { roz-ov-ičăk, } \\
\text { slănč-ev-ičăk, } \\
\text { roz-ov-at }\end{array}$ & $\begin{array}{l}\text { rose-DIM, } \\
\text { sunny-DIM, } \\
\text { rose-DIM }\end{array}$ \\
\hline & & $\mathrm{V}:-e j a$ & roz-ov-eja & become rose in color \\
\hline
\end{tabular}


Table 2 continued

\begin{tabular}{|c|c|c|c|c|}
\hline $\mathrm{SUFF}_{1}$ & $\begin{array}{l}\text { Syntactic } \\
\text { category } \\
\text { of } \text { SUFF }_{1}\end{array}$ & $\begin{array}{l}\text { SUFF }_{2} \text { according } \\
\text { to its syntactic } \\
\text { category }\end{array}$ & $\begin{array}{l}\text { Examples of } \\
\text { SUFF }_{1}-\text { SUFF }_{2} \\
\text { combinations }\end{array}$ & Translations \\
\hline $\begin{array}{l}\text {-ski/ } \\
\text {-ičeski/ } \\
\text {-eski/ } \\
\text {-ki/ } \\
\text {-ovski/ } \\
\text {-Vnski }\end{array}$ & ADJ & ?N: -ost & $\begin{array}{l}\text { ?det-sk-ost, } \\
\text { ?grad-sk-ost }\end{array}$ & $\begin{array}{l}\text { childish manner, } \\
\text { urban manner }\end{array}$ \\
\hline \multirow[t]{2}{*}{-tel } & $\mathrm{N}$ & $\mathrm{N}:-s t v o$ & uči-tel-stvo & $\begin{array}{l}\text { all teachers \& being } \\
\text { a teacher }\end{array}$ \\
\hline & & $\begin{array}{l}\mathrm{DIM}_{\mathrm{N}}:-\check{c} e \\
\mathrm{ADJ}:-s k i\end{array}$ & $\begin{array}{l}\text { uči-tel-če } \\
\text { uči-tel-ski }\end{array}$ & $\begin{array}{l}\text { teacher-DIM } \\
\text { teacher's }\end{array}$ \\
\hline -Vnie & $\mathrm{N}$ & $\begin{array}{l}\mathrm{DIM}_{\mathrm{N}}:-c e \\
\text { ADJ: }-s k i\end{array}$ & $\begin{array}{l}\text { koleb-anij-ce } \\
\text { upravl-en-ski }\end{array}$ & $\begin{array}{l}\text { hesitation-DIM } \\
\text { leader- }\end{array}$ \\
\hline \multicolumn{5}{|c|}{ DIMINUTIVE } \\
\hline$-\check{c} e$ & $\mathrm{~N}$ & DIM $_{\mathrm{N}}:$-ence & prăst-č-ence & finger-DIM-DIM \\
\hline$-c e$ & $\mathrm{~N}$ & DIM $_{\mathrm{N}}$ : -ence & pisăm-c-ence & letter-DIM-DIM \\
\hline -ence & $\mathrm{N}$ & DIM $_{\mathrm{N}}$ : -ence & det-ence-ence & child-DIM-DIM \\
\hline$-i c a$ & $\mathrm{~N}$ & $\mathrm{DIM}_{\mathrm{N}}:-k a,-i c a$ & $\begin{array}{l}\text { vod-ič- } k a \\
\text { bluz- } \check{c}-i \check{c}-i c a\end{array}$ & $\begin{array}{l}\text { water-DIM-DIM } \\
\text { blouse-DIM-DIM-DIM }\end{array}$ \\
\hline$-i c ̌ a ̆ a k$ & ADJ & 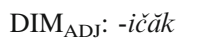 & $m a \breve{n}-i c ̌-i c ̌ a ̆ k$ & little-DIM-DIM \\
\hline$-k a$ & $\mathrm{~N}$ & $\mathrm{DIM}_{\mathrm{N}}:-i c a$ & $b l u z-\check{c}-i c a$ & blouse-DIM-DIM \\
\hline$-(o v) a t$ & ADJ & $\mathrm{DIM}_{\mathrm{ADJ}}:-i c \breve{a} \breve{k}$ & grub-ovat-ičăk & rude-DIM-DIM \\
\hline
\end{tabular}

noun. Moreover, for many native speakers socializămče is an unacceptable noun. In other words, the suffix -izăm tends to be closing in Bulgarian (Manova 2009b). However, since socializămče was found on the Internet, this suffix combination is seen as existing and it is thus considered in the present study.

As regards inflection, nominal, adjectival and verbal inflectional suffixes that occur in productive synthetic patterns will be considered. It is not possible to discuss also the unproductive inflectional patterns on the limited space of this article. Additionally, the unproductive inflection does not exhibit peculiarities that can invalidate the results of the present study.

Finally, it should be mentioned that all suffix combinations discussed in this paper are confirmed by some source, be it a dictionary, a grammar or the Internet. This fact is particularly important for the analysis of diminutives. Diminutive formation is a very productive rule in Bulgarian and diminutives are seldom listed in dictionaries. Moreover, diminitives are typical of the colloquial style and difficult to find in electronic corpora, since the latter are mainly based on written sources, which means formal discourse, where diminutives seldom occur. Many diminutive formations, especially those with more than one diminutive suffix, seem possible for some native speakers but doubtful and even impossible for others, which makes the 
verification of suffix combinations in which two or more diminutivizers participate extremely difficult. Therefore, in order to gain some objectiveness, double and triple diminutives cited in this paper are checked on the Internet (only on Bulgarian pages written in Cyrillic). A single occurrence on the Internet is seen as evidence that the diminutive exists.

\subsection{Method}

In accordance with the structure of the Bulgarian word, we will investigate the parsability of the derivational and inflectional slots separately. In both cases we will first discuss the structural properties of the suffixes and afterward whether they constitute a hierarchy of the type predicted by CBO.

As regards the information about suffix productivity this paper relies on, due to the above-mentioned difficulties with the use of the available electronic corpora, the productivity notes are based on descriptive studies of Bulgarian morphology and not on statistical calculations of frequency of occurrence of suffixes and bases, as is the case in the studies on parsability in English (see, for example, Zirkel's paper in this volume). Radeva $(1991,2007)$ are the most profound structural and semantic

Table 3 All combinations of the 22 suffixes under investigation with one another

\begin{tabular}{|c|c|}
\hline $\mathrm{SUFF}_{1}$ & $\mathrm{SUFF}_{2}$ \\
\hline$-(e)$ stvo & $-e n$ \\
\hline$-(i t) b a$ & $-e n,-i c a$ \\
\hline$-(i z) a c i j a$ & -onen, $-k a$ \\
\hline$-(l) i v$ & -ost, -ec, -ičak \\
\hline$-(n) i c a$ & $-e n,-k a$ \\
\hline -(on)en & -ost, -ica,-ota, -ičak \\
\hline$-e c$ & -estvo, $-k i /-e s k i$ \\
\hline -ik/-nik/-ovnik & -estvo, $-k i /-i c ̌ e s k i$ \\
\hline  & $?-\check{c} e$ \\
\hline -ost & -nik, -en, -iv, ?-ica \\
\hline$-o t a$ & $-e n$ \\
\hline$-o v /-e v$ & -ost,-ski, -ičăk,$-a t$ \\
\hline -ski/-ičeski/ -eski/-ki/-ovski/-Vnski & ?-ost \\
\hline -tel & $-s t v o,-s k i,-\check{c} e$ \\
\hline -Vnie & $-s k i,-c e$ \\
\hline \multicolumn{2}{|l|}{ DIMINUTIVE } \\
\hline$-\check{c} e$ & -ence \\
\hline$-c e$ & -ence \\
\hline -ence & -ence \\
\hline$-i c a$ & $-k a,-i c a$ \\
\hline  & $-i c \breve{c} \breve{k} k$ \\
\hline$-k a$ & $-i c a$ \\
\hline$-(o v) a t$ & $-i \check{c} \breve{a k}$ \\
\hline
\end{tabular}


descriptions of the Bulgarian word-formation and therefore serve as main sources of information about the productivity of the Bulgarian derivational suffixes. Inflectional suffixes investigated in this paper define the paradigms of the default inflectional classes in Bulgarian and are thus highly productive. If an unproductive inflectional suffix is discussed, the degree of its productivity is specified.

For the investigation of the parsability of the 22 derivational suffixes, we will use the suffix combinations listed in Table 3. The information that Table 3 provides is extracted from Table 2. Table 3, however, lists only the instances in which the 22 suffixes combine with one another. This makes our set of suffix combinations comparable with sets from other studies on parsability (see, for example, Zirkel in this volume) and also explains the smaller number of combinations in Table 3 in comparison to Table 2 .

Based on Table 3, I ordered the 22 derivational suffixes hierarchically as required by $\mathrm{CBO}$ and as done for English derivational suffixes by Hay and Plag (2004) and Plag and Baayen (2009). When ordering the suffixes hierarchically, I considered that diminutive suffixes always follow the other derivational suffixes, i.e. the 15 non-diminutive derivational suffixes and the seven diminutive suffixes were ordered separately and the two hierarchies were then combined. Additionally, the hierarchy of the 15 non-diminutive suffixes is quite underdetermined, i.e. some of the suffixes can be placed on more than one position without any violation of CBO. In such cases just one of the possible positions was selected. Since all these strategies made my task easier, I, in contrast to Plag and Baayen (2009) and Zirkel (this volume), managed to arrange my 22 suffixes hierarchically without the help of a computer. The hierarchy will be presented and discussed in the next section.

\section{Parsability in derivation}

As already mentioned in Sect. 1, Hay (2002 and later works) argues that parsability is related to productivity, semantic transparency and phonotactics. Unfortunately, for productivity I cannot provide an objective measure, due to the missing appropriate electronic corpora, therefore I will not discuss this criterion, though information about suffix productivity, if available from the descriptions of the Bulgarian word-formation, will always be provided. As regards semantic transparency, since the forms we discuss are derived by attachment of overt derivational suffixes, they are all semantically transparent. Semantic transparency can, however, exhibit different degrees, the most transparent being instances where a particular meaning is always expressed by one form only (cf. Dressler et al. 1987; Manova 2010). In what follows, I will demonstrate that it is not the case in Bulgarian where most of the suffixes have allomorphs (cf. Table 1), some productive and others less so. It is unclear how the Parsability Hypothesis treats allomorphy but it is obvious that the latter creates difficulties for the identification of a suffix, and it is hard to imagine that allomorphy can favour parsability. I will illustrate the problem with the very productive suffix -ski that derives relational adjectives in Bulgarian (cf. Radeva 2007 , p. 161ff). Since -ski can be attached to derived and non-derived bases, in the examples below if the base is derived, the suffix that precedes -ski is separated. 

a. vojn-ik 'soldier' $\rightarrow$ vojn- $i s$ - $k i$ 'soldier-'
b. uče-ník 'pupil' $\rightarrow$ uče-nić-eski 'pupil-'
c. upravl-énie 'government' $\rightarrow$ upravl-én-ski 'government-, governmental'
d. poved-énie 'behaviour' $\rightarrow$ poved-én-česki 'behaviour-, behavioural'
e. bár 'bar' $\rightarrow$ bár-ouski 'bar-'
f. póšta 'post' $\rightarrow$ póšt-enski 'post-'
g. tur-ist 'tourist' $\rightarrow$ tur-ist-ičeski 'tourist-'
h. Amérika 'America' $\rightarrow$ amerik-ánski 'American'
i. žába 'frog' $\rightarrow$ žáb-eski 'frog-'

As can be seen from these examples, the suffix -ski can appear in nine different shapes. Since allomorphy is very frequent in Bulgarian derivational morphology, we will conclude that with respect to morphotactic and morphosemantic transparency Bulgarian derivational suffixes are not optimal and are less transparent than English derivational suffixes.

As for phonotactics, which may also be a factor favoring parsability, due to the extensive allomorphy, differentiation of consonant-initial and vowel-initial suffixes is not always possible, since a suffix often has consonant-initial and vowel-initial variants (cf. Table 1). Additionally, a consonant-initial suffix may cause morphonological alternations, as in the above-cited vojnik $\rightarrow$ vojniš-ki (14a). Consider also $k n i g a$ 'book' $\rightarrow$ DIM kniž-ka 'little book' and istor-ik ,historian' $\rightarrow$ istor-ič-ka 'female historian'. Of course, one can claim that palatalizations, since occurring on the morpheme boundary only, serve as parsing cues. Compare, however, (14b) učenik $\rightarrow$ učenič-eski, with palatalization on the morpheme boundary, with $(14 \mathrm{~g})$ turist $\rightarrow$ turist-ičeski, the latter without palatalization but with the formal segment -česki that should have signaled a morpheme boundary. Moreover, the allomorph selection does not always depend on the termination of the base, cf. (14a-d), which is another argument that the morpheme boundary could not be a reliable parsing cue in Bulgarian. Further, according to the Parsability Hypothesis suffixes that cause stress changes are more difficult to parse in comparison to suffixes that do not change the stress pattern of the base. The Bulgarian derivational suffixes are, however, often stress-changing and in addition, a suffix can have neutral (14a-f,i) as well as stresschanging allomorphs $(14 \mathrm{~g}, \mathrm{~h})$, which makes $+/-$ stress-change a problematic structural criterion, too. I will not go further into analysis of the structural properties of the Bulgarian word-formation since the statistical tendencies, on which parsability hypothesis relies, only weakly correlate with structural properties. Nevertheless, I hope to have shown that what happens in Bulgarian word-formation in respect of morphotactics is hardly possible to favor parsing. I will therefore conclude that the structural criteria suggested by Hay do not appear very helpful for the analysis of the parsability of the Bulgarian word-formation; and if seen as related to parsability, the structural peculiarities exhibited by derived words should be interpreted as evidence that Bulgarian derivatives are overall difficult to parse.

My next goal is now to see whether the Bulgarian derivational suffixes can be ordered hierarchically in a CBO manner. If the 22 derivational suffixes under investigation order hierarchically, it would be further investigated whether the 
hierarchy has something to do with parsability or is due to other ordering principles, e.g. semantics seems a good candidate for a suffix ordering factor in derivational morphology. However, if the hierarchical ordering of the 22 suffixes is problematic, we will interpret it as evidence supporting the conclusion drawn on the basis of the structural factors discussed above, i.e. that parsability is not a relevant factor to derivational suffix combinations in Bulgarian.

The CBO hierarchy of the 22 suffixes under scrutiny in this study is shown in Table 4. As already discussed in the methodology section, Table 4 is based on the suffix combinations listed in Table 3.

In Table 4, all combinations that are above the diagonal formed by ' $\mathrm{X}$ ' obey $\mathrm{CBO}$, whereas the combinations below the ' $\mathrm{X}$ ' diagonal violate it. As can be seen from the table, six combinations are below the diagonal. Surprisingly, there are three combinations on the diagonal. This type of violation has not been attested in English suffixation (Plag and Baayen 2009) but in English prefixation (Zirkel, this volume). Five of all nine violations in Table 4 are due to mirror-image combinations, i.e. are instances of inside-outside suffix combinations that occur once as AB and then as BA. The three suffixes that attach recursively to themselves, i.e. form combinations that are on the diagonal, derive diminutives. Note that the mirror image combinations and the combinations that are on the diagonal cannot be avoided through rearrangement of the table, i.e. regardless how optimal our ordering is, these eight violations will always exist. In other words, the only CBO violation that can be eventually avoided through optimization of the hierarchy is the one marked by '?'. Plag and Baayen (2009) and Zirkel (this volume) achieve the optimal ordering of their affixes with the help of a computer algorithm. The violation marked by '?' on the hierarchy in Table 4, however, is a questionable combination of the suffixes -ski and -ost and I did not try to optimize the hierarchy. Thus, let me provide some explanation of the nature of the problematic combination and my decision.

Although both suffixes, -ski and -ost, are productive in Bulgarian, the combination $-s k i+-o s t$ is found only in Russian loanwords (for Russian, Sitchinava and Plungian 2009). Since -ski + -ost (i.e. -oskost) abstract nouns are non-native, they are not listed in any dictionary of Bulgarian. Moreover, the -oskost abstract nouns are typical of literary-criticism texts only and many native speakers are neither aware of the existence of this affix combination nor able to explain the meaning of the abstract nouns it derives. Additionally, the suffix $-s k i$ is closing in Bulgarian, i.e. there is no other derivational suffix that can follow -ski in Bulgarian (Manova 2009a). Thus, it is unclear whether the very few -skost nouns that have been borrowed from Russian should be treated as real Bulgarian nouns. I will therefore ignore this $\mathrm{CBO}$ violation. The instances of inside-outside order, however, deserve some attention.

Plag and Baayen (2009) investigate 31 English suffixes, and only two of them exhibit variable order. In my Bulgarian set of 22 suffixes, however, I find 10 suffixes which participate in mirror-image combinations. This difference between English and Bulgarian suffixes is statistically significant $(p=0.011$, two-tailed Fisher Exact Probability test). Notably, there is no statistical difference between the Bulgarian suffixes and the English prefixes investigated by Zirkel (this volume), which in eight out of 15 cases show mirror-image patterns. The following examples illustrate the variable order combinations in Table 4: 


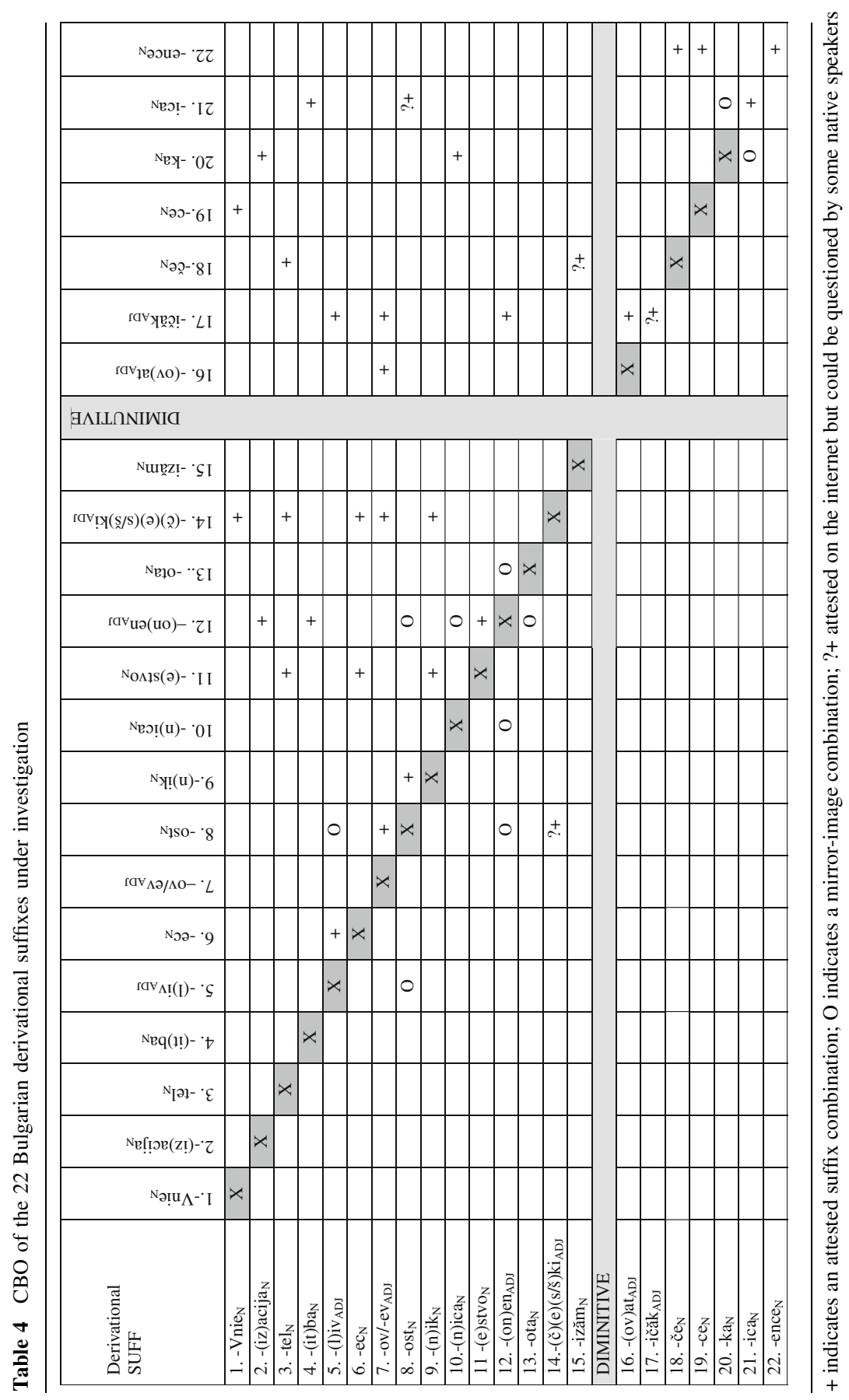


(15) - (l)iv \& -ost (see suffix 5 and suffix 8)
a. săn-liv 'sleepy' $\rightarrow$ săn-liv-ost 'sleepiness'
b. mil-ost 'mercy' $\rightarrow$ mil-ost-iv 'merciful'

(16) -en \& -ota (see suffix 12 and suffix 13)
a. mă̌́-en 'difficult' $\rightarrow$ măč-n-ota 'difficultness'
b. sam-ota 'loneliness' $\rightarrow$ sam-ot-en 'lonely'

(17) - ost \& -en (see suffix 8 and suffix 12)
a. rad-ost 'glad' $\rightarrow$ rad-ost-en 'gladness'
b. ver-en 'true, truthful' $\rightarrow$ vjar-n-ost 'truthfulness'

(18) -en \& -ica (see suffix12 and suffix 10)
a. vod-en 'water-' $\rightarrow$ vod-en-ica 'water mill'
b. mel-nica 'mill' $\rightarrow$ mel-nič-en 'mill-'

(19) DIM: -ica \& -ka (see suffix 21 and suffix 20)

a. răč-ica 'small hand' $\rightarrow r a \breve{c}-i \check{c}-k a$ 'very small hand'

b. kniž-ka 'small book' $\rightarrow k n i z ̌-c ̌-i c a$ 'very small book'

First, it should be mentioned that the above combinations differ in productivity. (18) is unproductive in both directions. (17) and (19) can be seen as productive in both directions. (15) and (16) are more productive in one direction. (15) is more productive as $-(l) i v+-o s t$ than as -ost $+-(l) i v$, whereas (16) is more productive as -en + -ota than as -ota + en. Let me illustrate the case of (16).

The Reverse Dictionary of Modern Bulgarian lists only four nouns that exhibit the combination -ota + -en (though there is a suffix -oten in Bulgarian, as in straxoten 'terrific'; there is, however, no noun *straxota, and thus straxoten should be derived from strax 'fear'). Of the four nouns that are derived via attachment of -ota + -en, only two (sam-ót-en 'lonely', derived from sam-otá 'loneliness', and čest-ót-en 'frequent', derived from čest-otá 'frequency') are really in use. The other two sram-ót-en 'shameless', derived from sramotá 'shame', and tég-ot-en 'difficult', derived from tegotá 'burden', are archaic forms, tégoten being the only derivative stressed on the first syllable. Actually, the parallel existence of -ota + -en derivatives and a suffix -oten is another illustration of the peculiar structural properties of the Bulgarian word. Fortunately, the -ota + -en derivatives are very few, which is due to the fact that the suffix -ota is otherwise closing in Bulgarian (Manova 2009a). This makes (16) a doubtful case of variable order. As already mentioned, (18) is unproductive in both directions, thus only (15), (17) and (19), which are to some extent productive, represent combinations that are highly problematic for a CBO hierarchy. It should be also noted that the unproductive -ota + -en and -oten derivatives are not the only case of this type in Bulgarian, the same problem occurs with very productive suffixes, such as the diminutivizers -ica, $-k a$ and -ička. Consider: glava 'head' $\rightarrow$ DIM1 glav-ica 'small head' $\rightarrow$ DIM2 glav-ič-ka 
'very small head' and čanta 'bag' $\rightarrow$ DIM čant-ička 'small bag', there is no DIM * čant$i c a$. Recall that -ica and $-k a$ also exhibit variable order (19).

The stronger tendency towards a recursive use of the same suffix in Bulgarian in comparison to English will be evidenced with recursive application of the same derivational suffix on non-adjacent and adjacent cycles. In Bulgarian, non-diminutive derivational suffixes may attach recursively on non-adjacent cycles. This type of recursiveness can be illustrated with the following examples:

(20) vod-en 'water-' $\rightarrow$ vod-en-ica 'watermill' $\rightarrow$ vod-en-ič-en 'watermill-' cjal 'whole' $\rightarrow$ cjal-ost 'whole, entirety' $\rightarrow$ cjal-ost-en 'comprehensive, exhaustive' $\rightarrow$ cjal-ost-n-ost 'comprehensiveness' 5

Similarly derived are also revn-ost-n-ost 'devotedness', verojatn-ost-n-ost '(greater) probability', povărx-nost-n-ost 'superficiality', (bez)lič-n-ost-n-ost '(without) (greater) personality'.

Recursive use of the same suffix on adjacent cycles was registered with diminutive suffixes only. This type of recursive ordering can be illustrated with the following examples that were found on the Internet:

$$
\begin{aligned}
\text { bluza 'blouse' } \rightarrow \text { DIM1 bluz-ka } & \\
\rightarrow \text { DIM2 bluz-č-ica } & \rightarrow \text { DIM3 bluz-č-ič-ica }
\end{aligned}
$$

$$
\begin{aligned}
& \text { dete 'child' } \rightarrow \text { DIM1 det-ence } \\
& \rightarrow \text { DIM2 det-enc-ence } \\
& \rightarrow \text { DIM3 det-enc-enc-ence }
\end{aligned}
$$

In fact, the examples in (20)-(22) are not as exotic as they could seem and illustrate one of the prototypical features of derivation in comparison to inflection, namely addition of lexical semantics. "[W]hereas an inflectional process is applied only once to a word in order to create a word form that fills a cell of a paradigm, derivational morphology may apply recursively because each derivational step may add some additional meaning" (Booij 2000, p. 365). Note that the adjectival diminutivizers may, like the nominal diminutivizers, attach recursively, on adjacent cycles, see the suffix -ičăk in Table 4. An example of a recursive use of -ičăk is available from Table 2 .

\footnotetext{
5 Such derivations are more typical of Russian (Sitchinava and Plungian 2009) than of Bulgarian (Manova 2009b). Consider the following Russian examples:

(i) revnostnost' (revn-iv-yj 'jealous' $\rightarrow$ revnost' 'jealousy' $\rightarrow$ revn-ost-n-yj 'devoted' $\rightarrow$ revn-ost-n-ost' 'devotedness')

verojatnostnost' (verojatn-yj 'probable' $\rightarrow$ verojatn-ost' 'probability' $\rightarrow$ verojatn-ost- $n-y j$ 'related to probability' $\rightarrow$ verojatn-ost-n-ost' '(greater) probability')

(bez)ličnostnost' (lico 'face' $\rightarrow$ lič-n-yj 'personal' $\rightarrow$ lič-n-ost' 'person, personality' $\rightarrow$ lič-n-ost-n-yj 'related to personality' $\rightarrow$ lič-n-ost-n-ost' '(greater) personality')
}

The above derivatives are typical of journalism, literary criticism and psychology texts (cf. Russian National Corpus, see also Švedova 1980). 
To this point, we could see that due to extensive allomorphy in Bulgarian, structural properties that favor parsing in English are difficult to use for Bulgarian. With respect to hierarchical $\mathrm{CBO}$, Bulgarian derivational suffixes exhibit peculiarities that are not registered in English suffixation, such as numerous instances of inside-outside order as well as recursive application of one and the same suffix on non-adjacent and adjacent cycles. Non-diminutive suffixes attach recursively on non-adjacent cycles, whereas diminutive suffixes attach recursively on adjacent cycles. 12 of the investigated 22 suffixes appear problematic for CBO. Since the diminutive suffixes always follow the other derivational suffixes and these two types of derivational suffixes exhibit different peculiarities with respect to cyclicity, I assume two derivational domains in the structure of the Bulgarian nouns and adjectives, a domain of non-diminutive suffixes and a domain of diminutive suffixes. The numerous cases of variable and recursive ordering in Bulgarian speak for a tendency towards cyclicity in this language and will be seen as evidence for a much lesser significance of parsability to Bulgarian derivational morphology than to English derivation. Additionally, the hierarchy is fairly underdetermined, the suffixes 1-4 allow many alternative orderings at the beginning of the hierarchy, and the suffix 15 could have any position on the hierarchy. These facts reveal further problems with the CBO hierarchy of the 22 suffixes under investigation. Overall, Bulgarian derivatives seem difficult to parse, and the CBO hierarchy of the derivational suffixes, due to multiple violations and being underdetermined, appears unconvincing.

In the next section, I will try to apply the predictions of the parsability hypothesis to affix combinations in the inflectional slot of the Bulgarian word, expecting that inflection, being prototypically more transparent and productive than derivation and not applying recursively (on the prototypical features of inflection, see Dressler 1989; Booij 2000), should behave better with respect to parsability.

\section{Parsability in inflection}

Before introducing the categories and features of the Bulgarian inflectional morphology, let me make a short comment on relative frequency and its relevance to inflection. It was mentioned in the Introduction that relative frequency is one of the factors that can serve as parsability measure (Hay 2001, 2002, 2003; Hay and Plag 2004). Hay (2001, 2002, 2003) defined relative frequency as the ratio of the frequency of the derivative to the frequency of the base. Unfortunately, such an understanding of relative frequency seems inapplicable to inflectional morphology since the bases that appear in inflected forms also appear in derived words and it is unclear where the occurrence of an inflectional base in a derivational formation forces parsability in inflection. To illustrate the problem, the verb igraja '(I) play', igraeš '(you) play', etc in the present tense; igrax '(I) played', igra 'you played', 
etc. in the aorist, has the present stem igrae-, the aorist stem igra-, and the root igr- (all forms of this verb are listed in the Appendix). All these three types of bases, however, occur not only in the different inflectional forms of the verb igraja but also in derivatives, such as igrač 'player', igračka 'toy', igrište 'playing court', igraene 'playing', etc. Based on my native speaker intuition, I would claim that the occurrence of inflectional bases in derivatives is irrelevant to the relative frequency of an inflectional suffix. Moreover, when in linguistics we speak of inflection in general, we usually mean (a) set(s) of affixes without their bases. These are, of course, just speculations and only a psycholinguistic investigation or an appropriate statistical measure (or a combination of both) would give some convincing answer to the question about the relation between inflectional bases in derivatives and parsability of inflectional forms, if any. Yet it seems to me that a hapax-based approach, comparable with that in Hay and Baayen (2002), Plag and Baayen (2009) and Zirkel (this volume) for derivational morphology, might be more promising than any investigation of productivity in inflection relying on relative frequency. To the best of my knowledge, however, hapax-based productivity has not been measured for inflection so far.

Let us now concentrate on the categories of the Bulgarian inflectional morphology. Bulgarian has very simple nominal inflection. Nouns inflect only for number and definiteness, whereas adjectives have inflection suffixes for gender, number and definiteness. Masculine inanimate nouns have a special count form that is used with cardinal numerals. Bulgarian verb inflection is very rich. Bulgarian has nine tenses in the indicative and every verb, irrespective of its aspect, can be used in every tense. Besides the voice and mood forms, Bulgarian has a set of evidential (renarrated) forms for five tenses and double renarrated forms for three tenses, and some mood forms can also be renarrated. In its diachronic development, Bulgarian lost the infinitive and now 1SG PRS IND serves as the citation form of the verb. The inflectional categories of Bulgarian are listed in Table 5 .

Table 5 Inflectional categories in Bulgarian

\begin{tabular}{|c|c|c|}
\hline Noun & Adjective & Verb \\
\hline $\begin{array}{l}\text { - number }(2)^{\mathrm{a}} \\
\text { (count plural for } \\
\text { masculine inanimates) } \\
\text { - definiteness } \\
\text { (suffixed definite article) }\end{array}$ & $\begin{array}{l}\text { - } \text { number (2) } \\
\text { - gender (3) } \\
\text { - definiteness } \\
\text { (suffixed } \\
\text { definite article) }\end{array}$ & $\begin{array}{l}\text { - person (3) } \\
\text { - number }(2) \\
\text { - tense ( } 9 \text { tenses in } \\
\text { indicat. active) } \\
\text { - aspect ( } 2) \\
\text { (no restrictions on the combination } \\
\text { of aspect and tense) } \\
\text { - mood ( } 3) \\
\text { - voice }(2) \\
\text { - evidentiality }(5+3) \\
\text { - gender ( } 3 \text {, in some analytic forms } \\
\text { and in } 3 \text { SG \& PL evidential) }\end{array}$ \\
\hline
\end{tabular}

\footnotetext{
a The numbers in brackets indicate the number of features of the respective category
} 


\subsection{Bulgarian noun inflection}

The inflectional slot in a Bulgarian noun has subslots for NUM and DEF suffixes:

\section{BASE-NUM-DEF ${ }^{6}$}

This template is illustrated in (24). For more examples and specific instances, see the detailed analysis of the Bulgarian noun inflection in Manova and Dressler (2001) and Manova (2003).



b. Žen- $a-\varnothing$ 'woman-SG'

$\check{z} e n-a-t a$ 'woman-SG-DEF'

žen-i-ø 'woman-PL'

As can be seen from these paradigms, in Bulgarian noun inflection, the first suffix after the base is always vowel-initial. If the subslot for number (the first subslot) in the inflectional slot is occupied, the next suffix is always consonant-initial.

\subsection{Bulgarian adjectival inflection}

The adjectival inflection of Bulgarian can be represented with the following template, where GEND and NUM share the same subslot, i.e. are cumulatively expressed (Matthews 1972):

\section{BASE-GEND/NUM-DEF}

\footnotetext{
${ }^{6}$ Anderson (2005, p. 111) claimed that the Bulgarian definite article is not a suffix but a clitic. Anderson motivated his claim with the fact that in Bulgarian only the first constituent of a DP carries an article. Consider: čanta 'bag' $\rightarrow$ čanta-ta 'bag-the' = 'the bag' and goljama čanta 'a big bag' $\rightarrow$ goljama-ta čanta 'big-the bag' = 'the big bag'. He assumed that the definite article moves from the noun to the adjective, which is not typical of a suffix, and he therefore assigned to the article the status of a clitic. His argument is, however, not entirely correct, since in Bulgarian it is also possible that both constituents of a DP are suffixed with a definite article, as in the sentence Čanta-ta goljama-ta mi daj! 'Give me the big bag!'. This example and the fact that the definite article is entirely integrated into the structure of the Bulgarian word show that the Bulgarian definite article is a suffix. On the morphological status of the Bulgarian definite article, see Stojanov (1993, p. 225ff); Bulgarian Academy Grammar (1998, p. 140f); Kucarov (1999, p. 469ff), among others.
} 
(26)
a. krasiv- $\varnothing-\varnothing$ 'beautiful' (masculine)
krasiv-ø-ijat 'beautiful-DEF'
b. krasiv- $a$ - $\varnothing$ 'beautiful-FEM/SG'
krasiv- $a$-ta 'beatuful-FEM/SG-DEF'
c. krasiv-o-ø 'beautiful-NEUT/SG'
krasiv-o-to 'beautiful-NEUT/SG-DEF'
d. krasiv-i-ø 'beautiful-PL'
krasiv-i-te 'beautiful-PL-DEF'

Note that adjectives do not inflect for gender in the plural in Bulgarian.

With respect to phonotactics, adjectival inflection is organized like noun inflection, i.e. the first suffix following the base is always vowel-initial. If there is a second suffix, it is always consonant-initial.

To sum up, in Bulgarian, in cases of two suffixes in the inflectional slot, of either a noun or an adjective, the first suffix is always vowel-initial whereas the second suffix is always consonant-initial, which is in harmony with the Parsability Hypothesis, since the latter sees consonant-initial suffix as more easily parsable than vowel-initial suffix. Nevertheless, noun and adjective inflection is not very rich and the established vowel-initial-consonant-initial order of inflectional suffixes may be irrelevant to the organization of the Bulgarian inflection. Thus let us see now whether the feature vowel-initial/consonant-initial plays any role in the order of the verbal inflectional suffixes. Note that the Bulgarian verb possesses the richest inflectional paradigm among the Slavic languages.

\subsection{Bulgarian verbal inflection}

The following template remains for the structure of a Bulgarian verb:

\section{PREF-BASE-ASP-TM-TNS/PER/NUM}

Since Bulgarian verbs are seldom derived, the BASE coincides with the verb root by default. TNS/PER/NUM are cumulatively expressed by a single suffix. As the different tenses exhibit different TMs by default (see Appendix), the structure of a Bulgarian verb can be seen as obeying the morpheme order established by Bybee (1985).

The category of aspect dominates Bulgarian verb morphology, and there are three types of verbs in Bulgarian: basic verbs (IPFV1), perfective verbs (PFV) and secondary imperfective verbs (IPFV2), each derived from the other, i.e. IPFV1 $\rightarrow$

\footnotetext{
7 The suffix -ijat is attached as one morpheme and its initial $-i$ is not the same as the $-i$ that marks plural in (26d). The $-i$ in -ijat is inherited from the long form of the Old Bulgarian adjectives. Modern Bulgarian does not distinguish between long and short adjectives, i.e. diachronically there were two suffixes: $-i$ - that made the adjective long, and -jat for definiteness. However, synchronically -ijat is a single suffix. Note that even if we assume two suffixes, the first suffix, $-i-$, is vowel-initial, whereas the second one begins with the glide $j$ that is a consonant.
} 
Table 6 Basic verbs in Bulgarian



$\mathrm{PFV} \rightarrow$ IPFV2. Basic verbs are imperfective by default and are thus called primary imperfectives (IPFV1). IPFV1 verbs are unmarked for aspect and exhibit the following structure: BASE-TM-TNS/PER/NUM. The present, aorist and imperfect forms of IPFV1 skărbja '(I) grieve' are listed in Table 6.

In Table 6, as everywhere in this paper, all examples are transliterated, which can lead to the misleading conclusion that the inflection suffixes -ja and -jat (1SG and 3PL PRS) are consonant-initial. In fact, $j$ is not a consonant but palatalises the preceding consonant, as can be seen from the phonological transcriptions: skărbja [skərb ${ }^{\mathrm{j}}$ ] and skărbjat [skərb ${ }^{\mathrm{j}}$ ət].

Perfective verbs are derived from basic verbs by prefixes by default. Prefixes add lexical semantics to basic verbs, and thus basic verbs and perfective verbs exhibit different, though related, semantic meaning (see Manova 2007 on perfectivization in Bulgarian). As regards the conjugation of perfective verbs, the latter, being derived by prefixation from basic verbs receive the same inflection, i.e. Bulgarian is a case of right-hand-headedness and the perfective verb o-skărbja '(I) insult' has the inflection of its base, the verb skărbja '(I) grieve' (Table 6).

Secondary imperfective verbs are derived from perfective verbs by addition of aspectual suffixes by default (Table 7). An imperfectivizing suffix is of the type $-(V) v$ - and is followed in all instances by the TM $-a$-, which allows for interpreting the sequence -ASP-TM- as a complex TM of the type -(V)va- (Manova 2005). The Bulgarian grammars never separate the aspectual marker from the TM (see the Academy Grammar 1998, p. 70; Stojanov 1993, p. 338, among others). In other words, although in the examples in Table 7, we write ASP and TM, the structure of a secondary imperfectives is PREF-BASE-[ASP(-)TM]-TNS/PER/NUM, that is PREF-BASE-(V)(v)a-TNS/PER/NUM.

If we scrutinize the forms in Table 6 , and Table 7 , we will see that the first suffix following the base is always either vowel-initial (Tables 6, 7a) or consonant initial (Table 7b), the second suffix, however, is always consonant-initial. Both types of ordering, BASE $+\mathrm{V}$-initial $+\mathrm{C}$-initial and BASE $+\mathrm{C}$-initial $+\mathrm{C}$-initial ${ }^{8}$ should favour

\footnotetext{
${ }^{8}$ Imperative inflection that attaches to vowel-final bases is of this type too (cf. Appendix), consider: $i g r a ́+j$ 'play! (IMP 2SG)', and igrá-j+te 'play! (IMP 2PL)'. Note that $-j$ is a glide.
} 
Table 7 Secondary imperfectives with (a) -Vva- and (b) -va-

\begin{tabular}{|c|c|c|c|}
\hline \multirow[t]{2}{*}{ (a) } & \multicolumn{3}{|c|}{ PREF-BASE-[ASP(-)TM]-TNS/PER/NUM } \\
\hline & PRESENT & AORIST & IMPERFECT \\
\hline $1 \mathrm{SG}$ &  &  &  \\
\hline $2 \mathrm{SG}$ & $o$-skărb-java-š &  & $o$-skărb-java-še \\
\hline $3 \mathrm{SG}$ & $o$-skărb-java & $o$-skărb-java & $o$-skărb-java-še \\
\hline $1 \mathrm{PL}$ & $o$-skărb-java-me & $o$-skărb-java-xme & $o$-skărb-java-xme \\
\hline $2 \mathrm{PL}$ & $o$-skărb-java-te & $o$-skărb-java-xte & $o$-skărb-java-xte \\
\hline \multirow[t]{2}{*}{$3 P L$} & $o$-skărb-java-t & $o$-skărb-java-xa &  \\
\hline & Present stem: oskărbjava- & Aorist stem: oskărbjava- & Imperfect stem: oskărbjava- \\
\hline \multirow[t]{3}{*}{ (b) } & \multicolumn{3}{|l|}{ pod-pis-va-m '(I) sign' } \\
\hline & \multicolumn{3}{|c|}{ PREF-BASE-[ASP(-)TM]-TNS/PER/NUM } \\
\hline & PRESENT & AORIST & IMPERFECT \\
\hline $1 \mathrm{SG}$ & pod-pis-va-m & pod-pis-va-x & pod-pis-va-x \\
\hline $2 \mathrm{SG}$ & pod-pid-va-̌̌ & pod-pid-va & pod-pid-va-še \\
\hline $3 \mathrm{SG}$ & pod-pis-va & pod-pis-va & pod-pis-va-̌̌se \\
\hline $1 \mathrm{PL}$ & pod-pis-va-me & pod-pis-va-xme & pod-pis-va-xme \\
\hline $2 \mathrm{PL}$ & pod-pis-va-te & pod-pis-va-xte & pod-pis-va-xte \\
\hline 3PL & pod-pis-va- $t$ & pod-pis-va-xa & pod-pis-va-xa \\
\hline & Present stem: podpisva- & Aorist stem: podpisva- & Imperfect stem: podpisva- \\
\hline
\end{tabular}

parsing (BASE+C-initial+V-initial would be unfavourable). In those combinations, the TM (the first suffix after the base) plays an important role. A TM indicates the end of a verb stem (see the stems in Tables 6 and 7) and associates that stem with a particular set of endings (recall that aspect suffixes together with the following TM - $a$ - form a complex TM). In other words, a TM signals a morphological boundary. Thus it appears that TMs in verbal inflection serve as parsing cues. This observation is further supported by the fact that stems serve as bases for the formation of participles, which could be seen as a kind of parallel to high frequency of the base in derivational morphology, i.e. favours parsing.

It should be mentioned that in the literature, there are analyses of the Bulgarian verb inflection that assume the existence of a special preterite marker $-x$-, see, for example, Stump (2001, Chap. 2), which is devoted to the paradigm of Bulgarian verbs. The assumption of a special preterite marker $-x$ - requires a different way of parsing of the aorist and imperfect paradigms. However, against parsing of $-x$ - and in favor of our analysis speaks the fact that there is no preterite stem in Bulgarian, i.e. the form BASE-TM-PRET- = BASE-TM- $x$ - neither occurs as a base of any verbal form nor feeds derivational morphology, whereas the aorist and the imperfect stems (both of the type BASE-TM-) do. Note that the way of parsing this study promotes is in consonance with all major sources on Bulgarian morphology that are written in Bulgarian (see Andrejčin 1978; The Bulgarian Academy Grammar 1983; Stojanov 1993) and Russian (Maslov 1981). 
Thus the established order in verbal inflection is parallel to what we found for Bulgarian noun and adjective inflection, wherein an overt suffix of number (in nominal inflection) or number/gender (in adjectival inflection), i.e. the first inflectional suffix, is followed in all instances only by consonant-initial suffixes. The first inflectional suffix is always vowel-initial in nouns, adjectives and most verbs (cf. Tables 6, 7a). Since Bulgarian inflection is organized around the differentiation of vowel-initial and consonant-initial suffixes, combinations of inflectional suffixes are much easier to segment and parse than combinations of derivational suffixes.

Let us check now whether the inflectional suffix combinations can be ordered hierarchically according to $\mathrm{CBO}$. As we could see above, the Bulgarian inflectional morphology is templatically organized, which means a fixed order of suffixes and makes inflectional suffix combinations easy to describe hierarchically. The templates are sequences of slots for different categories. In every slot, we have the set of suffixes that express the respective category but never co-occur in that slot. The order of the Bulgarian inflectional suffixes is summarized in Tables 8, 9, and 10 where all existing combinations of inflectional suffixes (categories) are marked by ' + '.

Tables 8, 9, and 10 are word-class-based and thus do not completely conform to $\mathrm{CBO}$, which puts all suffixes, irrespective of their syntactic category, on one and the same hierarchy. The inflectional suffixes of the different word classes, however, do not occur together, i.e., for example noun inflection cannot be followed by verb inflection or vice versa. This fact seems to speak against ordering of all inflectional suffixes on a single hierarchy, but does not mean that such ordering is impossible.

Table 8 Order of the noun inflection

\begin{tabular}{lcc}
\hline Category expressed by a set of suffixes & NUM & DEF \\
\hline NUM & $X$ & + \\
DEF & & $X$ \\
\hline
\end{tabular}

Table 9 Order of the adjectival inflection

\begin{tabular}{lcc}
\hline Category expressed by a set of suffixes & GEND/NUM & DEF \\
\hline GEND/NUM & $\mathrm{X}$ & + \\
DEF & & $\mathrm{X}$ \\
\hline
\end{tabular}

Table 10 Order of the verbal inflection

\begin{tabular}{lccc}
\hline Category expressed by a set of suffixes & ASP & TM & TNS/PER/NUM \\
\hline ASP & $\mathrm{X}$ & + & \\
TM & & $\mathrm{X}$ & + \\
TNS/PER/NUM & & & $\mathrm{X}$ \\
\hline
\end{tabular}


Table 11 CBO of the Bulgarian inflection

\begin{tabular}{|c|c|c|c|c|c|c|c|}
\hline \multirow[b]{2}{*}{ SUFF1 } & \multicolumn{7}{|l|}{ SUFF2 } \\
\hline & $\begin{array}{l}\text { 1. } \mathrm{NUM}_{\mathrm{N}} \\
\text { SUFFs }\end{array}$ & $\begin{array}{l}\text { 2. DEF } \\
\text { SUFFs }\end{array}$ & $\begin{array}{l}\text { 3. GEND/NUM } \\
\text { SUIJ } \\
\text { SUFs }\end{array}$ & $\begin{array}{l}\text { 4. } \mathrm{DEF}_{\mathrm{ADJ}} \\
\text { SUFFs }\end{array}$ & $\begin{array}{l}\text { 5. ASP } \\
\text { SUFFs }\end{array}$ & $\begin{array}{l}\text { 6. } \mathrm{TM}_{\mathrm{V}} \\
\text { SUFFs }\end{array}$ & $\begin{array}{l}\text { 7. TENSE/ } \\
\text { PER/ } \\
\text { NUM }_{V} \\
\text { SUFFs }\end{array}$ \\
\hline 1. $\mathrm{NUM}_{\mathrm{N}}$ SUFFs & $\mathrm{X}$ & + & & & & & \\
\hline 2. $\mathrm{DEF}_{\mathrm{N}} \mathrm{SUFFs}$ & & $\mathrm{X}$ & & & & & \\
\hline $\begin{array}{l}\text { 3. GEND/NUM } \\
\text { SUFJ } \\
\text { SUFs }\end{array}$ & & & $\mathrm{X}$ & + & & & \\
\hline 4. $\mathrm{DEF}_{\mathrm{ADJ}} \mathrm{SUFFs}$ & & & & $\mathrm{X}$ & & & \\
\hline 5. ASP $\mathrm{AUFF}_{\mathrm{V}}$ & & & & & $X$ & + & \\
\hline 6. $\mathrm{TM}_{\mathrm{V}}$ SUFFs & & & & & & $\mathrm{X}$ & + \\
\hline $\begin{array}{l}\text { 7. TENSE/PER/ } \\
\text { NUM }_{V} \\
\text { SUFFs }\end{array}$ & & & & & & & $\mathrm{X}$ \\
\hline
\end{tabular}

Table 11 is a CBO hierarchy of the Bulgarian inflection. The respective category slots are seen as consisting of subslots where all suffixes that express a given inflectional category are listed, each suffix in a separate subslot. Since the suffixes of a particular inflectional category never co-occur in the same slot, the list of all suffixes, like the list of all categories, will order hierarchically. I will therefore not list all suffixes but only the inflectional categories. This is also for practical reasons, a list of all inflectional suffixes will make the table very big and difficult to place on a single page.

As can be seen from Table 11, Bulgarian inflectional suffixes can be ordered in a hierarchy, which is a fact that is in line with the predictions of CBO. The hierarchy of the inflectional suffixes is, however, highly underdetermined, the suffixes of three categories (see 1, 3 and 5), out of the seven categories listed in Table 11, never follow other suffixes, which means that many different orderings will satisfy CBO. This fact seriously questions a CBO hierarchy of the inflectional suffixes in Bulgarian.

To sum up, Bulgarian inflectional suffixes are better parsable than the derivational suffixes. They are templatically organized and strictly obey a hierarchical order. The CBO hierarchy of the inflectional suffixes is, however, underdetermined.

\section{Conclusion}

In this article, I have challenged the Parsability Hypothesis (CBO) with data from the inflecting-fusional morphological type, as represented by the South Slavic language Bulgarian. I have defined the structure of the Bulgarian word and showed that one should distinguish between derivational and inflectional suffix slots. Since Bulgarian stacks suffixes in both these slots, I have investigated the parsability of 
the derivational and the inflectional slots separately. I have shown that derivation and inflection differ with respect to parsability. Inflectional suffix combinations are more easily parsable than derivational suffix combinations. Derivational suffixes often exhibit variable order and the same derivational suffix may attach recursively on adjacent and non-adjacent cycles. Variable order and recursiveness are, however, incompatible with CBO. Intriguingly, the Bulgarian derivational suffixes under investigation in this paper have more in common with English prefixes (Zirkel, this volume) than with English suffixes (Plag and Baayen 2009).

With respect to recursiveness and productivity, the Bulgarian word can be seen as having three domains: a non-diminutive derivational domain, a diminutive domain and an inflectional domain. In Bulgarian, a non-diminutive derivational suffix can be attached recursively on non-adjacent cycles only, a diminutive suffix can be attached recursively on adjacent cycles only, and an inflectional suffix never attaches recursively. The suffixes of the inflectional domain are the most productive of all, the diminutive suffixes are less productive than the inflectional suffixes but more productive than the non-diminutive derivational suffixes.

The results of this study show that Bulgarian suffixes are compatible with hierarchy-based ordering but the hierarchy they constitute cannot be due to parsability. Moreover, the CBO hierarchies of derivational and inflectional suffixes are significantly underdetermined. Further research is needed to establish the factor(s) that underlines the hierarchical order of the Bulgarian suffixes.

Overall, the results of this study can be seen as conforming to the last revision of the Parsability Hypothesis (Baayen et al. 2009). Baayen et al. claim that in English, "the combinatorial ordering constraints first discussed by Hay and Plag (2004), and characterized as constraints working against cycles in the directed suffix graph by Plag and Baayen (2009), are stronger for the Germanic stratum than for the Nonnative stratum suffixes', Thus, if we see the derivational suffix slot and the inflectional suffix slot of the Bulgarian word as parallel to the non-native stratum and the Germanic stratum respectively in English word-formation, we can conclude that suffixes that are closer to the root tend to exhibit idiosyncrasies and appear less parsable in both languages.

Acknowledgements I would like to thank Ingo Plag for all his insightful comments and criticism and for serving as editor of the paper. I am also grateful to two anonymous reviewers, and especially to Harald Baayen. The research reported in the paper was supported through Elise Richter Fellowship, grant V64-G03 from the Austrian Science Fund (FWF). The support is gratefully acknowledged.

Open Access This article is distributed under the terms of the Creative Commons Attribution Noncommercial License which permits any noncommercial use, distribution, and reproduction in any medium, provided the original author(s) and source are credited.

\section{Appendix}

See Table 12. 







\section{References}

Anderson, S. R. (2005). Aspects of the theory of clitics. Oxford: Oxford University Press.

Andrejčin, L. (Ed.). (1975). Obraten rečnik na săvremennija bălgarski ezik [Reverse dictionary of Modern Bulgarian]. Sofija: BAN.

Andrejčin, L. (1978). Osnovna bălgarska gramatuka [Basic Bulgarian Grammar]. Sofija: Nauka i izkustvo.

Andrejčin, L., Asenova, P., Georgieva, E., Ivanova, K., Nicolova, R., Pašov, P., Părvev, X., Rusinov, R., Stankov, V., Stojanov, S., \& Čolakova, K. (1983). Gramatika na săvremennija bălgarski knižoven ezik. Tom II. Morfologija [Grammar of Modern Bulgarian Literary Language, Vol. II: Morphology]. Sofija: Izdatelstvo na BAN. Reprinted in 1998. Sofija: Abagar.

Aronoff, M., \& Fuhrhop, N. (2002). Restricting suffix combinations in German and English: Closing suffixes and the monosuffix constraint. Natural Language \& Linguistic Theory, 20(3), 451-490.

Baayen, H., Kryuchkova, T., \& Vickerman, A. (2009). Ordering constraints in English derivation and compounds. Paper presented at the 2nd Vienna workshop on affix order. Vienna, June 5-6, 2009. Abstract: http://homepage.univie.ac.at/stela.manova/2nd_workshop_abstracts/abstract_baayen_ et_al.pdf. Accessed 13 December 2009.

Baayen, H., \& Plag, I. (2008). Parsing is not weaklessness: suffix ordering revisited. Paper presented at the Workshop on affix ordering in typologically different languages. Vienna, February 3-4, 2008. Abstract: http://homepage.univie.ac.at/stela.manova/workshop_imm13/abstracts/baayen_plag.pdf. Accessed 13 December 2009.

Booij, G. (2000). Inflection and derivation. In G. Booij, C. Lehmann, \& J. Mugdan (Eds.), Morphology. An international handbook on inflection and word-formation (Vol. 1, pp. 360-369). Berlin: Walter de Gruyter.

Bulgarian Academy Grammar (1983, 1998) = Andrejčin et al. (1983).

Bybee, J. L. (1985). Morphology. A study of the relation between meaning and form. Amsterdam: Benjamins.

Dressler, W. U. (1989). Prototypical differences between inflection and derivation. Zeitschrift für Phonetik, Sprachwissenschaft and Kommunikationsforschung, 42, 3-10.

Dressler, W. U., Mayerthaler, W., Panagl, O., \& Wurzel W. U. (1987). Leitmotifs in Natural Morphology. Amsterdam: Benjamins.

Gaeta, L. (2008). From competence to performance: The Copernican revolution of affix ordering. Paper presented at the Workshop on affix ordering in typologically different languages. Vienna, February 3-4, 2008. Abstract: http://homepage.univie.ac.at/stela.manova/workshop_imm13/ abstracts/Gaeta.pdf Accessed 13 December 2009.

Hay, J. (2001). Lexical frequency in morphology: Is everything relative? Linguistics, 39(6), 1041-1070.

Hay, J. (2002). From speech perception to morphology: Affix-ordering revisited. Language, 78(3), $527-555$.

Hay, J. (2003). Causes and consequences of word structure. London: Routledge.

Hay, J., \& Baayen, H. (2002). Parsing and productivity. In G. E. Booij \& J. van Marle (Eds.), Yearbook of morphology 2001 (pp. 203-255). Dordrecht: Kluwer.

Hay, J. \& Plag, I. (2004). What constrains possible suffix combinations? On the interaction of grammatical and processing restrictions in derivational morphology. Natural Language and Linguistic Theory, 22, 565-596.

Kucarov, I. (1999). Morfologija. In T. Bojadžiev, I. Kucarov, \& J. Penčev. Săvremenen bălgarski ezik. Fonetika. Leksikologija. Slovoobrazuvane. Morfologija. Sintaksis (pp. 277-497) [Modern Bulgarian. Phonetics. Lexicology. Word-Formation. Morphology. Syntax]. Sofija: P. Beron.

Langacker, R. W. (1987). Foundations of Cognitive Grammar, Vol. I: Theoretical prerequisites. Stanford: Stanford University Press.

Manova, S. (2002). Between inflection and derivation: On morphotactic expression of aspect and gender in Bulgarian, Russian and Serbo-Croatian. Wiener Slavistisches Jahrbuch, 48, 203-217.

Manova, S. (2003). An input-oriented approach to inflection class assignment illustrated with Bulgarian nominal inflection. Wiener Slavistisches Jahrbuch, 49, 103-118.

Manova, S. (2005). Derivation versus Inflection in three Inflecting Languages. In W. U. Dressler, D. Kastovsky, O. Pfeiffer, \& F. Rainer (Eds.), Morphology and its demarcations: Selected papers from the 11th International Morphology Meeting, Vienna, February 2004 (pp. 233-252). Amsterdam: Benjamins. 
Manova, S. (2007). On derivation-inflection character of Bulgarian aspect. Die Welt der Slaven, LII(1), 21-46.

Manova, S. (2008). Closing suffixes and the structure of the Slavic word: Movierung. Austrian Contributions to the 14th International Congress of Slavists, Ohrid, Macedonia, September 2008. Wiener Slavistisches Jahrbuch, 54, 91-104.

Manova, S. (2009a). Closing suffixes in Bulgarian, Russian and German: The role of semantics. In Farkas Baráthi, M. (Ed.), Bulgarian Language and Literature in Slavic and Non-Slavic Contexts, http:// homepage.univie.ac.at/stela.manova/manova_szeged2009.pdf. Accessed 13 December 2009.

Manova, S. (2009b). A cognitive approach to SUFF1-SUFF2 combinations. Manuscript of a paper presented at the 2nd Vienna Workshop on Affix Order. Vienna, June 5-6, 2009. Abstract: http:// homepage.univie.ac.at/stela.manova/2nd_workshop_abstracts/abstract_manova.pdf. Accessed 13 December 2009.

Manova, S. (2010). Understanding morphological rules. Conversion and subtraction in Bulgarian, Russian and Serbo-Croatian. Dordrecht: Springer.

Manova, S., \& Dressler, W. U. (2001). Gender and declensional class in Bulgarian. Wiener Linguistische Gazette, 67-69, 45-81.

Maslov, J. S. (1981). Grammatika bolgarskogo jazyka [A grammar of Bulgarian]. Moskva: Vysšaja škola.

Matthews, P. H. (1972). Inflectional morphology: A theoretical study based on aspects of Latin Verb conjugation. Cambridge: Cambridge University Press.

Plag, I. (2002).The role of selectional restrictions, phonotactics and parsing in constraining suffix ordering in English. In G. Booij \& J. van Marle (Eds.), Yearbook of morphology 2001 (pp. 285-314). Dordrecht: Kluwer.

Plag, I., \& Baayen, H. (2009). Suffix ordering and morphological processing. Language, 85(1), 109-152.

Radeva, V. (1991). Bălgarskoto slovoobrazuvane [Bulgarian word-formation]. Sofija: Universitetsko izdatelstvo 'Sv. Kliment Oxridski'.

Radeva, V. (2007). V sveta na dumite [In the world of words]. Sofija: Universitetsko izdatelstvo 'Sv. Kliment Oxridski'.

Reverse dictionary of modern Bulgarian = Andrejčin (ed.) 1975.

Russian National Corpus $=$ http://www.ruscorpora.ru/.

Sitchinava, D., \& Plungian, V. (2009). Closing suffixation patterns in Russian, with special reference to the Russian National Corpus. Paper presented at the 2nd Vienna workshop on affix order: Affix order in Slavic and languages with similar morphology, Vienna, 5-6 June 2009. Abstract: http://homepage.univie.ac.at/stela.manova/2nd_workshop_abstracts/abstract_sitchinava_plungian.pdf. Accessed 13 December 2009.

Skalička, V. (1979). Typologische Studien. P. Hartmann, (ed.). Wiesbaden: Braunschweig.

Stojanov, S. (1993). Gramatika na bălgarskija knižoven ezik [A Grammar of Literary Bulgarian]. V izdanie. Sofija: Universitetsko izdatelstvo "Sv. Kl. Oxridski”,

Stump, G. T. (2001). Inflectional morphology. A theory of paradigm structure. Cambridge: Cambridge University Press.

Švedova, N. J. (Ed.). (1980). Russkaja grammatika. Tom I. Fonetika, Fonologija, Udarenie, Intonacija, Slovoobrazovanie, Morfologija [Russian Grammar I. Phonetics, phonology, stress, intonation, wordformation, morphology]. Moskva: Izdatel'stvo 'Nauka' (Izdatel'stvo Akademii Nauk SSSR).

Zirkel, L. (this volume). Prefix combinations in English: structural and processing factors. 